\title{
SELF EFFICACY TERHADAP MATEMATIKA MELALUI PENDEKATAN APTITUDE TREATMENT INTERACTION
}

\author{
Irma Fitri \\ Pendidikan Matematika, FTK UIN Sultan Syarif Kasim Riau
}

\begin{abstract}
This study aims to determine differences in mathematics self-efficacy among students who learn to use the Aptitude Treatment Interaction (ATI) approach with students receiving conventional learning. This study is a quasiexperimental research, where teachers who play a direct role in the learning process and there researcher as an observer. Subjects in this study were 32 students on grade VIII SMP Negeri 2 Bangkinang Pekanbaru. Data collected by aptitude tests, observation, test result, and questionnaire. The result of this experiment indicated that self-efficacy scores students who learn using ATI approach and students receive conventional learning are different.
\end{abstract}

Keywords: Aptitude treatment interaction; Self efficacy

\section{PENDAHULUAN}

Belajar dapat membawa perubahan bagi seseorang, baik perubahan pengetahuan, sikap, maupun keterampilan. Adanya perubahan-perubahan tersebut, tentunya seseorang akan terbantu dalam memecahkan permasalahan hidup dan bisa menyesuaikan dengan lingkungannya. Belajar tidak hanya mampu untuk mengetahui, tapi mampu untuk memahami, terutama pelajaran yang bersifat eksak dan merupakan ilmu dasar untuk pelajaran lainnya, seperti matematika. Matematika merupakan salah satu ilmu dasar yang mempunyai peranan penting dalam penguasaan ilmu pengetahuan dan teknologi, baik aspek penerapannya maupun aspek penalarannya. Penguasaan siswa terhadap ilmu pengetahuan dan teknologi didasari atas penguasaan matematika. (Hudoyo, 1990).

Menurut Risnawati (2008), pembelajaran matematika adalah proses memperoleh pengetahuan yang dibangun oleh siswa sendiri dan harus dilakukan sedemikian rupa sehingga dapat memberikan kesempatan kepada siswa untuk menemukan kembali konsep-konsep matematika. Adapun tujuan pembelajaran matematika adalah agar siswa mampu memecahkan masalah yang meliputi kemampuan memahami masalah, merancang model matematika, menyelesaikan model dan menafsirkan solusi yang diperoleh, serta mampu mengomunikasikan gagasan dengan simbol, tabel, diagram, atau media lain untuk memperjelas keadaan atau masalah (Permendiknas, 2006). Berdasarkan tujuan pembelajaran tersebut, aspek sikap dan pengetahuan siswa 
diperlukan. Salah satu aspek sikap yang perlu dimiliki adalah rasa percaya diri yang identik dengan self efficacy (Risnawati, 2012). Jadi, self efficacy sangat penting dimiliki oleh siswa.

Self efficacy adalah keyakinan diri siswa terhadap kemampuannya dalam pembelajaran matematika. Semakin tinggi self efficacy yang dimiliki, akan semakin baik kegiatan yang dilakukan dalam berbagai tugas dan tanggung jawabnya (Herawaty, 2016). Siswa dengan self efficacy yang rendah mungkin menghindari pelajaran yang banyak tugasnya, khususnya untuk tugas-tugas yang menantang. Sedangkan, siswa dengan self efficacy yang tinggi mempunyai keinginan yang besar untuk mengerjakan tugas-tugasnya (Aisyah, 2008). Self efficacy memiliki empat prinsip, yaitu: (1) self efficacy dapat meningkatkan prestasi pribadi; (2) self efficacy dapat meningkat atau menurun jika melihat orang lain yang memiliki keberhasilan atau kegagalan yang sama pada suatu tugas tertentu; (3) self efficacy dapat timbul jika seseorang diberi sugesti mampu untuk mengerjakan suatu tugas, tapi jika gagal self efficacy tersebut akan hilang; (4) self efficacy memiliki hubungan dengan tekanan emosional. Bandura (1994) menjelaskan indikator self efficacy terdiri dari tiga hal, yaitu: (1) pengalaman kinerja (performance experience) yang didasarkan pada penilaian/pengalaman kinerja sebelumnya; (2) pengalaman orang lain (vicarious experience) yang didasarkan pada perbandingan kompetensi dan informatif dengan hasil yang dicapai orang lain; (3) aspek dukungan langsung/sosial (verbal persuasion) yang mengacu pada umpan balik langsung/kata-kata dari guru atau orang lain yang lebih dewasa.

Berdasarkan wawancara dengan guru mata pelajaran matematika di SMP Negeri 2 Bangkinang Pekanbaru, didapatkan bahwa self efficacy siswa terhadap matematika tergolong rendah. Guru telah berusaha memberikan soal yang berbeda-beda pada siswa, akan tetapi usaha guru tersebut belum dapat meningkatkan self efficacy mereka. Hal ini dapat terlihat dari masih banyak siswa yang mengerjakan pekerjaan rumah di sekolah dan menyontek pekerjaan rumah teman. Banyak siswa yang menyontek kepada temannya yang dianggap lebih pintar ketika ujian. Hal ini menunjukkan bahwa siswa tersebut lebih meyakini jawaban yang dikerjakan oleh temannya.

Hal ini sejalan dengan penelitian Warsito (2009) bahwa terdapat 19 mahasiswa $(31,67 \%)$ kurang berusaha menyelesaikan tugas tepat waktu dengan berbagai alasan, 11 mahasiswa $(18,33 \%)$ mudah menyerah dengan keadaan seperti saat kondisi banyak tugas sehingga kurang yakin dapat menyelesaikan tugas-tugas tersebut, dan 30 
mahasiswa (50\%) merasa kurang yakin akan kemampuannya untuk dapat memenuhi ketentuan-ketentuan akademik yang begitu banyak. Berdasarkan hal tersebut dapat diambil kesimpulan bahwa banyak mahasiswa kurang yakin dengan kemampuannya yang ditunjukkan dengan mahasiswa kurang berusaha, cepat menyerah dengan masalah, kurang serius dalam perkuliahan, cepat merasa puas dengan hasil yang dicapai. Dengan kata lain, ciri-ciri tersebut menunjukan mahasiswa memiliki self efficacy yang rendah.

Bila di kalangan mahasiswa saja masih demikian, apalagi di kalangan siswa. Oleh karena itu, salah satu cara untuk mengatasi permasalahan tersebut adalah dengan menggunakan pendekatan Aptitude Treatment Interaction (ATI). ATI merupakan pembelajaran yang dapat melayani perbedaan individual siswa, yaitu menyesuaikan perlakuan/treatment (metode pembelajaran) dengan karakteristik siswa. Pada penerapannya, lebih menekankan kepada pemberian perlakuan (treatment) yang berbeda dalam pembelajaran, sesuai dengan karakteristik masing-masing kelompok siswa (tinggi, sedang, dan rendah). Dengan cara ini diharapkan tercipta hasil belajar yang optimal. Optimalisasi hasil belajar dapat dicapai melalui penyesuaian antara pembelajaran (treatment) dengan perbedaan kemampuan (aptitude) siswa (Nurdin, 2005).

Perlakuan (treatment) yang diberikan kepada siswa didasarkan atas kemampuan (aptitude) siswa akan berpengaruh pada tingkat self efficacy siswa tersebut. Bagi siswa yang memiliki rasa percaya diri kurang atau sulit dalam menyesuaikan diri, cenderung belajarnya akan lebih baik bila berada dalam lingkungan belajar yang sangat terstruktur. Sebaliknya, siswa yang memiliki rasa percaya diri yang tinggi (independent), belajarnya akan lebih baik dalam situasi pembelajaran yang agak longgar (fleksibel) (Nurdin, 2005). Risnawati (2012) menjelaskan bahwa terdapat perbedaan self-efficacy matematika siswa yang diajarkan dengan model Problem Based Instruction pendekatan ATI dan konvensional pada siswa ber-IQ rendah, sedangkan pada siswa ber-IQ tinggi dan ber-IQ sedang tidak terdapat perbedaan. Sesuai dengan masalah yang telah dikemukakan sebelumnya, tujuan penelitian ini untuk menguji perbedaan self efficacy terhadap matematika antara siswa yang belajar menggunakan pendekatan ATI dengan siswa yang memperoleh pembelajaran konvensional. 


\section{METODE PENELITIAN}

Penelitian ini merupakan penelitian quasi eksperimental. Subjek dalam penelitian ini adalah 32 siswa kelas VIII SMP Negeri 2 Bangkinang Pekanbaru. Selanjutnya dikelompokkan berdasarkan hasil tes IQ. Hasil dari tes IQ ini dikelompokkan menjadi tiga kategori, yaitu kelompok tinggi dengan (nilai lebih dari 101), kelompok sedang (nilai 90 - 101), dan kelompok rendah (nilai di bawah 90). Sedangkan objek dalam penelitian ini adalah self efficacy siswa terhadap matematika.

Teknik pengumpulan data yang digunakan dalam penelitian ini adalah lembar aptitude tests (tes IQ), observasi, dan angket. Aptitude tests digunakan untuk mengklasifikasikan siswa berdasarkan tingkat kemampuannya. Observasi menggunakan lembar pengamatan untuk mengamati kegiatan guru dan siswa yang diharapkan muncul dalam pembelajaran matematika dengan pendekatan ATI. Angket digunakan untuk melihat perkembangan self efficacy siswa. Teknik analisis data yang digunakan pada penelitian ini adalah uji statistik $t$ ( $t$ test).

\section{HASIL DAN PEMBAHASAN}

Pendekatan ATI dalam penelitian ini dilakukan dalam empat tahap, yaitu (1) Perlakuan (treatment) awal, pemberian perlakuan awal terhadap siswa dengan menggunakan aptitude testing dimaksudkan untuk menentukan dan menetapkan klasifikasi kelompok siswa berdasarkan tingkat kemampuan sekaligus untuk mengetahui potensi kemampuan masing-masing siswa dalam menghadapi informasi/pengetahuan baru; (2) Pengelompokan siswa, pengelompokan siswa berdasarkan hasil aptitude testing, diklasifikasikan menjadi tiga kelompok yang terdiri atas siswa berkemampuan tinggi, sedang, dan rendah; (3) Memberikan perlakuan (treatment), pada masing-masing kelompok diberikan perlakuan yang dipandang cocok/sesuai dengan karakteristiknya. Siswa yang berkemampuan tinggi diberikan perlakuan berupa selflearning melalui modul plus yaitu belajar secara mandiri melalui modul dan buku-buku teks matematika yang relevan.Kemudian siswa yang memiliki kemampuan sedang dan rendah diberikan pembelajaran secara konvensional. Selanjutnya siswa yang kemampuan rendah diberikan lagi perlakuan dalam bentuk re-teaching dan tutorial yang bisa diberikan lagi oleh guru atau tutor yang sudah menerima petunjuk dan bimbingan dari guru; dan (4) Achievement test, setiap pelaksanaan dilakukan penilaian prestasi akademik/hasil belajar setelah diberikan perlakuan pembelajaran kepada masing-masing kelompok. 
Pelaksanaan pembelajaran matematika dalam penelitian ini pada kelompok eksperimen dilakukan dalam enam pertemuan. Pertemuan pertama dilakukan dengan Sistem Persamaan Linier Dua Variabel (SPLDV). Pada kegiatan ini, kelompok siswa dengan kemampuan matematika tinggi diberikan modul, soal-soal latihan, dan kunci jawaban. Sedangkan untuk kelompok siswa dengan kemampuan matematika sedang dan kemampuan matematika rendah diberikan pembelajaran konvensional. Guru menjelaskan materi dan siswa diberi kesempatan untuk bertanya. Pada kegiatan penutup diperoleh kesimpulan bahwa Sistem Persamaan Linier Dua Variabel adalah persamaan linier yang memiliki dua variabel yang masing-masing berpangkat satu dimana nilainya tidak diketahui.

Pada pertemuan kedua, materi pembelajaran dilakukan pada penyelesaian sistem persamaan linier dua variabel dengan metode grafik. Pada kegiatan ini, guru melakukan kegiatan seperti pada pertemuan pertama. Kesimpulan yang didapat pada kegiatan ini adalah himpunan penyelesaian persamaan linier dua variabel berupa garis lurus.

Pada pertemuan ketiga, materi pembelajaran pada penyelesaian sistem persamaan linier dua variabel dengan metode substitusi dan eliminasi. Pada kegiatan ini, guru mengulas materi yang telah dipelajari pada pertemuan sebelumnya. Guru memberitahukan dan mengingatkan pembelajaran masih menggunakan pendekatan ATI seperti pertemuan pertama dan kedua. Kesimpulan yang didapat pada kegiatan ini, metode substitusi adalah cara penyelesaikan sistem persamaan linier dua variabel dengan memasukkan persamaan yang lebih sederhana ke dalam persamaan lain. Sedangkan untuk menyelesaikan sistem persamaan linier dua variabel dengan metode eliminasi, yaitu dengan menghilangkan salah satu variabel dengan menyamakan koefisien dari variabel yang akan dihilangkan.

Pada pertemuan keempat, materi pembelajaran pada penyelesaian sistem persamaan linier dua variabel dengan metode gabungan eliminasi dan substitusi. Pada kegiatan ini, guru melakukan kegiatan yang sama seperti sebelumnya. Kesimpulan yang didapat adalah penyelesaian sistem persamaan linier dua variabel bisa dengan memadukan metode substitusi dan eliminasi.

Pada pertemuan kelima, materi pembelajaran pada membuat model matematika dalam kehidupan sehari-hari dan menyelesaikan model tersebut. Pada kegiatan ini, guru melakukan kegiatan yang sama seperti sebelumnya. Kesimpulan yang didapat pada 
kegiatan iti adalah permasalahan dalam kehidupan sehari-hari dapat diselesaikan dengan melalui model matematika yang melibatkan sistem persamaan linier dua variabel.

Pada pertemuan keenam, materi pembelajaran tidak dilakukan dengan pendekatan ATI, melainkan melakukan re-teaching dan tutor sebaya. Selanjutnya dibagikan angket yang digunakan untuk mengetahui perkembangan self efficacy siswa.

Data hasil angket self efficacy siswa terdiri atas angket awal dan angket akhir. Angket awal diberikan sebelum penerapan pendekatan ATI. Sedangkan, angket akhir diberikan setelah penerapan pendekatan ATI. Data tersebut diuji homogenitas dan normalitasnya. Kemudian dianalisis untuk mengetahui adanya self efficacy siswa terhadap matematika melalui pendekatan ATI.

Uji homogenitas kemampuan awal dengan taraf signifikan $(\alpha)=0,05$ diperoleh bahwa pada kelompok tinggi $\mathrm{F}_{\text {hitung }}<\mathrm{F}_{\text {tabel }}$ atau $1,15<4,74$, maka varians-varians adalah homogen. Pada kelompok sedang, $F_{\text {hitung }}<F_{\text {tabel }}$ atau $1,14<2,39$, maka varians-varians adalah homogen. Sedangkan pada kelompok rendah, $\mathrm{F}_{\text {hitung }}<\mathrm{F}_{\text {tabel }}$ atau 1,68<6,0, maka variansvarians adalah homogen. Uji normalitas menggunakan uji Liliefors disajikan pada Tabel 1.

Tabel 1. Hasil uji normalitas dengan uji Liliefoirs

\begin{tabular}{cccc}
\hline Kelompok & Kelas & $\mathbf{L}_{\text {hitung }}$ & $\mathbf{L}_{\text {tabel }}$ \\
\hline \multirow{2}{*}{ Tinggi } & Eksperimen & 0,2422 & 0,319 \\
& Kontrol & 0,1124 & 0,249 \\
\multirow{2}{*}{ Sedang } & Eksperimen & 0,2234 & 0,250 \\
& Kontrol & 0,1075 & 0,206 \\
\multirow{2}{*}{ Rendah } & Eksperimen & 0,1764 & 0,258 \\
& Kontrol & 0,2365 & 0,337 \\
\hline
\end{tabular}

Berdasarkan Tabel 1, diketahui bahwa $\mathrm{L}_{\text {hitung }}<\mathrm{L}_{\text {tabel }}$ sehingga $\mathrm{H}_{\mathrm{o}}$ diterima. Dengan demikian, dapat disimpulkan bahwa kelas berdistribusi normal.

Uji normalitas kemampuan akhir siswa didasarkan pada skor angket dari kelas eksperimen (pendekatan ATI) dan kelompok kontrol (pembelajaran konvensional). Pada kelompok rendah, diperoleh $\mathrm{L}_{\text {hitung }}<\mathrm{L}_{\text {tabel, }}$ maka data berdistribusi normal. Selanjutnya dianalisis dengan uji $t$. Nilai $t_{\text {hitung }}=8,25$ berarti bahwa $t_{\text {hitung }}>\mathrm{t}_{\text {tabel }}$, maka diputuskan bahwa $\mathrm{H}_{\mathrm{o}}$ ditolak dan $\mathrm{H}_{\mathrm{a}}$ diterima. Dengan demikian, dapat disimpulkan bahwa terdapat perbedaan self efficacy siswa yang belajar menggunakan pendekatan ATI dengan siswa yang memperoleh pembelajaran konvensional pada kelompok rendah. Pada kelompok sedang, diperoleh $\mathrm{L}_{\text {hitung }}<\mathrm{L}_{\text {tabel }}$, maka data berdistribusi normal. Nilai $\mathrm{t}_{\text {hitung }}=11,98$ berarti bahwa $t_{\text {hitung }}>\mathrm{t}_{\text {tabel}}$, maka diputuskan bahwa $\mathrm{H}_{\mathrm{o}}$ ditolak dan $\mathrm{H}_{\mathrm{a}}$ diterima. Dengan demikian, dapat disimpulkan bahwa terdapat perbedaan self efficacy siswa yang belajar 
menggunakan pendekatan ATI dengan siswa yang memperoleh pembelajaran konvensional pada kelompok sedang. Sedangkan pada kelompok tinggi, diperoleh $\mathrm{L}_{\text {hitung }}<\mathrm{L}_{\text {tabel}}$, maka data berdistribusi normal. Nilai $\mathrm{t}_{\text {hitung }}=3,57$ berarti bahwa $\mathrm{t}_{\text {hitung }}>$ $\mathrm{t}_{\text {tabel}}$, maka diputuskan bahwa $\mathrm{H}_{\mathrm{o}}$ ditolak dan $\mathrm{H}_{\mathrm{a}}$ diterima. Dengan demikian, dapat disimpulkan bahwa terdapat perbedaan self efficacy siswa yang belajar menggunakan pendekatan ATI dengan siswa yang memperoleh pembelajaran konvensional pada kelompok tinggi.

Peningkatan yang signifikan pada kelas eksperimen dikarenakan dalam pembelajaran di kelas, guru menerapkan prinsip dari pendekatan ATI, yaitu pembelajaran yang mengelompokkan siswa berdasarkan kelompok homogen. Dengan kelompok yang homogen, siswa lebih yakin dengan kemampuannya dan tidak hanya berharap dari siswa lain yang dianggap lebih mampu. Siswa kelompok tinggi belajar dengan modulnya dan siswa yang kelompok sedang dan rendah memperoleh pembelajaran konvensional. Kemudian pada kelompok rendah diadakan re-teaching dengan maksud agar siswa mengulang kembali pembelajaran. Pada penelitian ini, reteaching dilakukan pada pertemuan terakhir sebelum angket akhir. Hal ini bertujuan agar guru bisa mengontrol kegiatan tersebut.

Pada kelompok tinggi, siswa belajar mandiri. Sedangkan pada kelompok rendah, guru mengulang-ulang pelajaran dan menjelaskan jika ada materi yang kurang dimengerti. Pada siswa kelompok sedang, mereka mempelajari kembali materi yang telah diajarkan. Setelah pelaksanaan re-teaching, achievement test diberikan sebagai tes akhir pembelajaran.

Pada pertemuan pertama, pembelajaran dengan pendekatan ATI belum berjalan dengan lancar karena masih banyak siswa yang bingung dengan penempatan kelompoknya. Selain itu, lebih banyak waktu yang dihabiskan dalam mengumpulkan kembali siswa dari kelompok tinggi dan melakukan refleksi. Pada pertemuan kedua dan ketiga siswa sudah mulai mengerti dengan alasan pengelompokkan yang dilakukan. Pada pertemuan keempat, proses pembelajaran dengan pendekatan ATI sudah berjalan dengan lancar, dimana guru telah melakukan langkah-langkah dalam pendekatan ATI dengan baik dan siswa juga sudah terbiasa dalam pengelompokkan tersebut. Pada pertemuan kelima, proses pembelajaran dengan pendekatan ATI lebih disempurnakan sehingga semua langkah-langkah pendekatan ATI dilaksanakan dengan sangat baik oleh guru dan siswa. 
Berdasarkan $t_{\text {hitung }}$ tentang self efficacy siswa pada pokok bahasan Sistem Persamaan Linear Dua Variabel menunjukkan bahwa mean self efficacy pada kelas yang menggunakan pendekatan ATI lebih tinggi daripada mean self efficacy pada kelas yang memperoleh pembelajaran konvensional. Hal ini menunjukkan bahwa pendekatan ATI dalam pembelajaran matematika memiliki perbedaan yang signifikan, dimana self efficacy kelas eksperimen lebih tinggi daripada self efficacy pada kelas kontrol.

\section{SIMPULAN DAN SARAN}

Hasil penelitian menunjukkan bahwa terdapat perbedaan skor self efficacy siswa yang belajar menggunakan pendekatan ATI dengan siswa yang memperoleh pembelajaran konvensional.

Sebaiknya siswa kelompok rendah tidak didiskriminasi dalam proses pembelajaran untuk menghindari kecemburuan sosial. Selain itu, juga diperlukan persiapan yang baik agar proses pembelajaran berjalan dengan lancar, efektif, dan bermanfaat. Guru harus mendesain modul secara baik agar siswa dapat memahaminya dengan mudah dan tidak terjadi kesalahpahaman konsep. Dalam melaksanakan pendekatan ATI diperlukan dua ruang belajar, satu untuk kelompok tinggi dan satu untuk kelompok sedang dan rendah. Ruang belajar yang kondusif sangat diperlukan, terutama untuk kelompok tinggi karena kelompok tinggi memerlukan kenyamanan dalam belajar secara mandiri.

\section{DAFTAR RUJUKAN}

Aisyah. (2008). Pengaruh self efficacy, kecerdasan emosional, keinovatifan, komitmen organisasi terhadap kinerja pejabat eselon III PEMDA Kota Palembang. Jakarta: Universitas Negeri Jakarta.

Bandura, A. (1994). Self-efficacy. In V. S. Ramachaudran (Ed.), Encyclopedia of Human Behavior (Vol. 4, pp.71-81). New York: Academic Press.

Herawaty, D. (2016). Pengaruh kecerdasan emosional, partisipasi guru dalam forum ilmiah, keyakinan diri (self efficacy), dan motivasi kerja terhadap kinerja guru matematika. JRPM (Jurnal Review Pembelajaran Matematika), 1(1), 71-85. doi:10.15642/jrpm.2016.1.1.71-85

Hudoyo, H. (1990). Pengembangan kurikulum matematika dan pelaksanaannya di depan kelas. Surabaya: Usaha Nasional. 
Kusaeri, K. (2012). Estimasi parameter item dan latent class dengan model DINA untuk diagnosis kesulitan belajar. Jurnal Ilmu Pendidikan, 18(2), 187-193.

Nurdin, S. (2005). Model pembelajaran yang memperhatikan keragaman individu siswa dalam kurikulum berbasis kompetensi. Ciputat: Quantum Teaching.

Peraturan Menteri Pendidikan Nasional RI No. 22 Tahun 2006 tentang Standar Isi untuk Satuan Pendidikan Dasar dan Menengah. Jakarta: Kemendiknas RI.

Risnawati. (2008). Strategi Pembelajaran Matematika. Pekanbaru: Suska Press.

Risnawati. (2012). Pengaruh model problem based instruction (PBI) dalam pendekatan aptitude treatment instruction terhadap pemahaman konsep siswa dan self efficacy siswa di SMPN kota Pekanbaru. Prosiding Seminar Nasional Matematika dan Pendidikan Matematika 2012: Peranan Matematika Sebagai Ilmu Pengetahuan Dasar dalam Meningkatkan Mutu Pendidikan Nasional, 31 Oktober 2012. Padang. Jurusan Matematika FMIPA Universitas Andalas.

Warsito, H. (2012). Hubungan antara self-efficacy dengan penyesuaian akademik dan prestasi akademik (Studi Pada Mahasiswa FIP Universitas Negeri Surabaya). Pedagogi: Jurnal Ilmu Pendidikan, 9(1), 29-47. 